\title{
Prenatal Stress Inhibits Neuronal Maturation through Downregulation of Mineralocorticoid Receptors
}

\author{
Makoto Tamura, ${ }^{1 \star}$ Mari Sajo, ${ }^{1 \star}$ Akiyoshi Kakita, ${ }^{2}$ Norio Matsuki, ${ }^{1}$ and Ryuta Koyama ${ }^{1}$ \\ ${ }^{1}$ Laboratory of Chemical Pharmacology, Graduate School of Pharmaceutical Sciences, The University of Tokyo, Tokyo 113-0033, Japan, and ${ }^{2}$ Brain Science \\ Branch Center for Bioresources, Brain Research Institute, University of Niigata, Niigata, 950-2181, Japan
}

Prenatal stress (PS) increases the risk of depressive disorders in adult offspring. The pathophysiology of depressive disorders has been linked to hippocampal dysfunction; however, whether and how PS attenuates the development and function of hippocampal networks remains unknown. Using a rat model of PS, in which pregnant mothers receive daily restraint stress during late gestation and their offspring exhibit depressive-like behavior later in life, we show that PS impairs the morphological and functional maturation of hippocampal granule cells in adult offspring via the downregulated expression of mineralocorticoid receptors. PS reduced the dendritic complexity and spine density of neonatal-generated granule cells, which persists into adulthood. These granule cells exhibited depressed synaptic responses to stimulation of the medial perforant path. We further revealed that the expression of mineralocorticoid receptors, which we found is necessary for proper dendritic maturation in this study, was significantly downregulated in granule cells after PS. These results suggest that PS-induced downregulation of mineralocorticoid receptors attenuates neuronal maturation, which results in dysfunction of neuronal network in adulthood.

\section{Introduction}

Maternal stress during pregnancy increases the risk of depressive disorders in the adult offspring, which suggests that the adverse effects of prenatal stress (PS) are programmed in the brain persistently (Weinstock, 2007). However, the cellular and molecular mechanisms underlying the phenomena are unclear. We examined whether PS influences the development and function of hippocampal networks, whose dysfunction has been strongly implicated in the pathophysiology of depressive disorders (Sheline, 1996). It has been suggested that the disruption in hippocampus-dependent regulation of the hypothalamic-pituitary-adrenal axis (HPA axis), which leads to an abnormal increase in plasma corticosteroid hormone levels in response to stressors, is associated with the episodes of depressive disorders (Nestler et al., 2002).

In the hippocampal networks, the dentate granule cells play a crucial role in receiving, filtering, and transmitting neural inputs from the entorhinal cortex to hippocampal pyramidal cells ( $\mathrm{Hsu}$,

Received July 3, 2010; revised June 15, 2011; accepted June 16, 2011.

Author contributions: N.M. and R.K. designed research; M.T., M.S., and R.K. performed research; A.K. and R.K. contributed unpublished reagents/analytic tools; M.T., M.S., and R.K. analyzed data; M.T., M.S., and R.K. wrote the paper.

*M.T. and M.S. contributed equally to this work.

This work was supported in part by Grants-in-Aid for Young Scientists (B) (21790059) and Scientific Research (22390012) from The Ministry of Education, Culture, Sports, Science, and Technology and in part by Grants-in-Aid for JSPS Fellows (191838 and 10-10592) from the Japan Society for the Promotion of Science. We are grateful to Dr. Tatsunori Seki for generously providing anti-PSA antibody and to Dr. Takashi Namba for instructing us in retrovirus injection.

Correspondence should be addressed to Ryuta Koyama, Laboratory of Chemical Pharmacology, Graduate School of Pharmaceutical Sciences, The University of Tokyo, 7-3-1 Hongo, Bunkyo-ku, Tokyo 113-0033, Japan. E-mail: rkoyama@mol.f.u-tokyo.ac.jp.

DOI:10.1523/JNEUROSCI.3447-10.2011

Copyright $\odot 2011$ the authors $\quad 0270-6474 / 11 / 3111505-10 \$ 15.00 / 0$
2007). Thus, the dentate granule cells are likely related to the etiology of depressive disorders; however, whether and how PS affects the maturation of granule cells remains unknown.

In this study, using a rat model of PS, we examined the influences of PS on the granule cell maturation and incorporation into hippocampal networks. PS reduced the dendritic complexity and spine density of granule cells in offspring examined at postnatal day 60 (P60). Although it has been reported that PS reduces the dendritic complexity of granule cells (Hosseini-Sharifabad and Hadinedoushan, 2007), we further found that synaptic responses of granule cells to stimulation of the medial perforant path (MPP) were depressed in PS rats. Furthermore, we suggest a novel molecular mechanism underlying the malformation of dendrites: proper expression of mineralocorticoid receptors, which we show is necessary for dendritic development, is inhibited by PS. These results indicate that the adverse effects of PS persist into adulthood as a result of morphological and functional deficits in granule cells.

\section{Materials and Methods}

All experimental procedures conformed to the National Institutes of Health (NIH) Guidelines for the Care and Use of Laboratory Animals and to the guidelines provided by the University of Tokyo.

Pharmacological agents. Spironolactone, fludrocortisone, and aldosterone were obtained from Sigma.

PS. Pregnant rats (Wistar/ST), obtained from SLC, were kept in quiet facilities under controlled temperatures $\left(22-23^{\circ} \mathrm{C}\right)$ and a controlled light schedule (lights were on from 7:00 A.M. to 7:00 P.M.) with access to food and water ad libitum. PS was performed as described previously (Lemaire et al., 2000). Briefly, pregnant rats were subjected daily to three sessions of restraint stress ( $45 \mathrm{~min}$ each) in small cylindrical cages $(6.4 \mathrm{~cm}$ diameter) while being exposed to bright light. The stress was given during the last week of pregnancy, i.e., during embryonic days 15-21. Control rats were undisturbed in their home cages. We mainly presented the data 
from female offspring in this study (see Figs. 1-8) (supplemental Figs. S1-S5, available at www.jneurosci.org as supplemental material). The data from male offspring are shown in Figures 9-11 and supplemental Figure S6 (available at www.jneurosci.org as supplemental material).

Organotypic culture of hippocampal slices. Entorhino-hippocampal slice cultures (300 $\mu \mathrm{m}$ thick) were prepared from $\mathrm{P} 0$ rat pups as described previously (Koyama et al., 2007). Briefly, slices were placed on Omnipore membrane filters (JHWP02500; Millipore), cultured in a solution containing $50 \%$ minimal essential medium, 25\% horse serum (Cell Culture Lab), and 25\% HBSS, and incubated at $37^{\circ} \mathrm{C}$ in a humidified incubator containing $5 \%$ $\mathrm{CO}_{2}$ and $95 \%$ air. The medium was changed every 2.5 d. Finally, cultured samples were fixed by immersion in $4 \%$ PFA at $4^{\circ} \mathrm{C}$ for $24 \mathrm{~h}$.

Retroviral vector. To visualize the morphology of newborn granule cells, a membranetargeted yellow fluorescent protein (mYFP) (Takara Bio) sequence was inserted into the multicloning site of the pDON-AI-2 DNA retroviral vector (Takara Bio). The expression of mYFP was regulated by the human cytomegalovirus (CMV) promoter.

To knock down mineralocorticoid receptors, short hairpin RNA (shRNA) sequences targeting rat mineralocorticoid receptor were incorporated into the retroviral vector pSIRENRetroQ-ZsGreen (Takara Bio), in which ZsGreen, a green fluorescent protein, is expressed under the control of the CMV promoter. Mineralocorticoid receptor shRNA (MR shRNA) was coexpressed under the control of the human U6 promoter. The target sequence (5'-GGATGTGTCTATCATCGTT-3'; nucleotides 2881-2899) was selected by Dragon Genomics Center (Takara Bio). As a negative control, we used a nontargeting shRNA ( $5^{\prime}$ TCTTAATCGCGTATAAGGC-3') generated by the manufacturer (Takara Bio).

Retrovirus preparation. Retroviruses were produced by G3T-hi cells (Takara Bio) and cotransfected with the expression vector and two helper plasmids [gag-pol expression plasmid and vesicular stomatitis virus glycoprotein (VSVG) expression plasmid; both from Takara Bio] using a calcium phosphate-mediated gene transfer system. Briefly, G3T-hi cells were seeded on collagen type I-coated $100 \mathrm{~mm}$ cell culture dishes (BD Biosciences). After growing to $80-90 \%$ confluence, the cells were transfected with gag-pol, VSVG, and the retroviral vector. For transfection, DNA (10 $\mu \mathrm{g}$ each) was diluted in Tris/EDTA buffer containing $125 \mathrm{~mm} \mathrm{CaCl}_{2}$. The mixture was then diluted in HEPES buffer and added to the culture medium. After $7 \mathrm{~h}$ of transfection, the media were changed. Viruscontaining supernatant was harvested at 31,55 , and $79 \mathrm{~h}$ after the beginning of transfection. The viral solution was spun at $780 \times g$ for $15 \mathrm{~min}$, passed through a $0.45 \mu \mathrm{m}$ filter, and centrifuged at $65,000 \times g$ for 120 min (Beckman rotor; Beckman Coulter). The pellet was then resuspended in $100 \mu \mathrm{l}$ of PBS. Retroviruses were stored at $-80^{\circ} \mathrm{C}$ until use. The final titer was $\sim 10^{8} \mathrm{pfu} / \mathrm{ml}$ as determined using NIH/3T3 cells.

Retrovirus injection in vivo and in vitro. To infect newborn neurons in vivo, P0 rats that were deeply anesthetized on ice were stereotactically injected with $0.5 \mu \mathrm{l}$ of retrovirus into the dentate gyrus region (anteroposterior, $1.1 \mathrm{~mm}$ from lambda; lateral, $\pm 1.6 \mathrm{~mm}$; ventral, $1.8 \mathrm{~mm}$ ). It has been reported that retrovirus was distributed within $200-400 \mu \mathrm{m}$ of the injection site (Seki et al., 2007). In this study, we observed that $\sim 50$
B
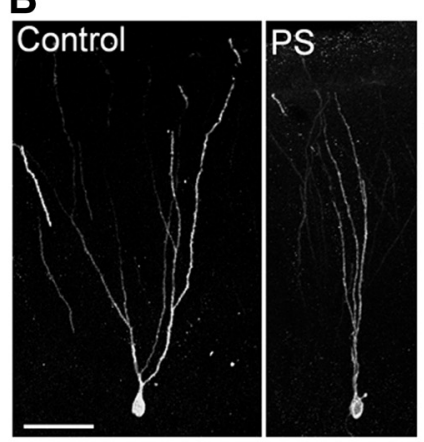

Control

PS
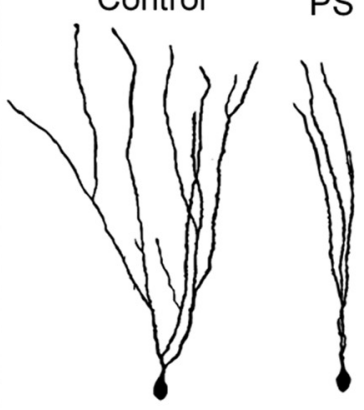

D
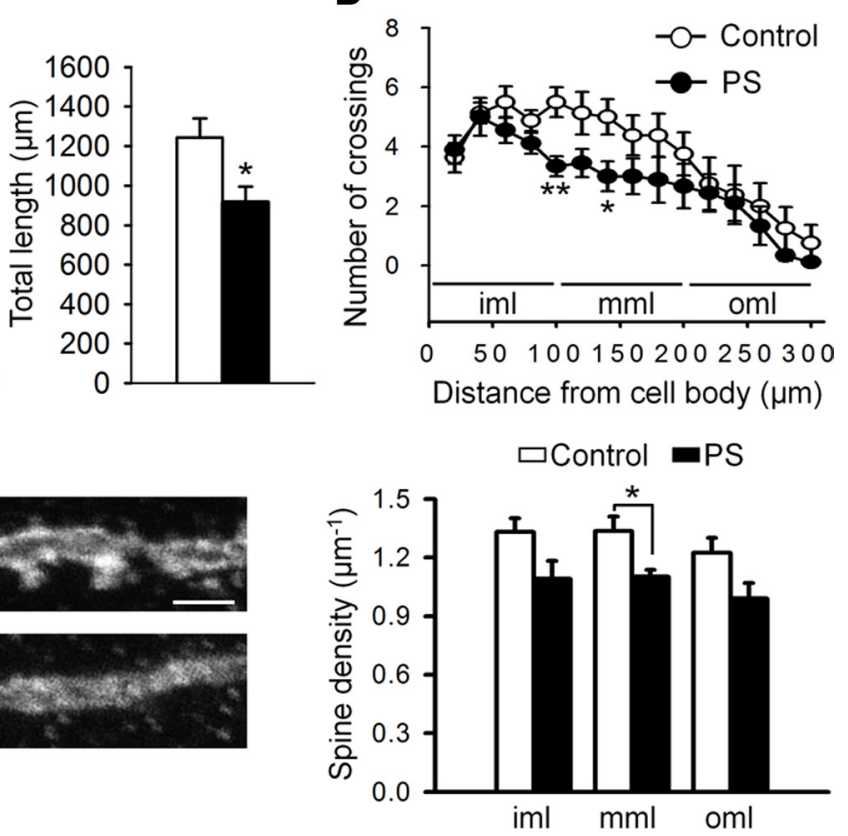

im

$\mathrm{ml}$

Figure 1. PS attenuates morphological maturation of postnatal-generated granule cells in adulthood. $A, A$ confocal image of an mYFP-expressing granule cell immunostained for Prox1 in P60 rat dentate gyrus. gcl, Granule cell layer. $\boldsymbol{B}$, Representative images of granule cells from control and PS rats. Right, Tracings of granule cells. C, Quantification of the number of branch points and the

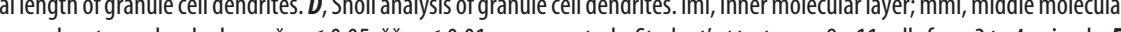
Spine density of granule cell dendrites was significantly decreased in the middle molecular layer. iml, Inner molecular layer; $\mathrm{mml}$, middle molecular layer; oml, outer molecular layer. ${ }^{*} p<0.05$ versus controls; Student's $t$ test. $n=9$ cells from 3 to 4 animals. Values represent means \pm SEM. Scale bars: $\boldsymbol{A}, \boldsymbol{B}, 50 \mu \mathrm{m} ; \boldsymbol{E}, 2 \mu \mathrm{m}$.

granule cells were infected by retrovirus within $400 \mu \mathrm{m}$ of the injection site (data not shown). However, there are a few number of granule cells whose morphologies were obviously traced, because most of the infected granule cells existed closely with their dendrites frequently overlapping each other. Thus, for the dendritic analyses, we assessed two to three granule cells per animal in the suprapyramidal blade of the granule cell layer.

To infect new neurons in cultured slices, a few microliters of retrovirus solution were placed on cultured slices soon after slice preparation. We observed less than three granule cells per slice whose morphologies were clearly visualized by retrovirus-mediated gene transfer in cultured slices. Thus, we analyzed all granule cells observed.

Dendritic arborization of granule cells was analyzed in a blind manner in all the experiments.

BrdU labeling. To label newborn neurons, 5-bromo- $2^{\prime}$-deoxyuridine (BrdU) (100 mg/kg; Sigma) was subcutaneously injected twice a day into $\mathrm{P} 0-\mathrm{P} 1$ rats or added to the culture medium of hippocampal slices at a concentration of $1 \mu \mathrm{M}$ within 30 min of beginning the culture.

Tissue preparation for dendritic and immunohistochemical analyses for in vivo study. Experimental animals were deeply anesthetized with di- 

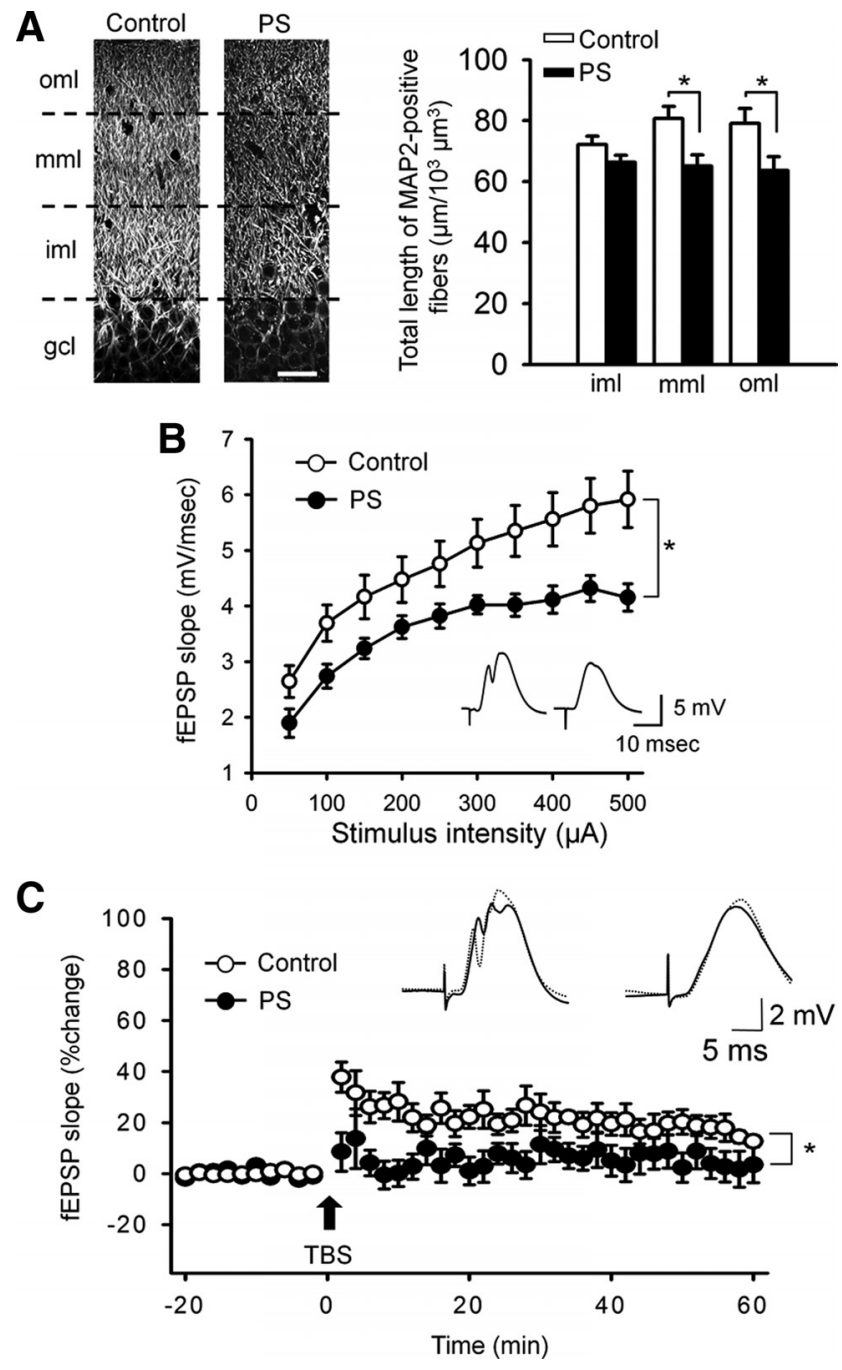

Figure 2. Long-lasting effects of PS on the anatomy and function of granule cell dendrites. $\boldsymbol{A}$, Left, Immunohistochemical images of MAP2 in the molecular layer at P60. gcl, Granule cell layer; iml, inner molecular layer; $\mathrm{mml}$, middle molecular layer; oml, outer molecular layer. Right, The density of MAP2-positive processes in each subregion of the molecular layer. ${ }^{*} p<$ 0.05 versus control animals; Student's $t$ test. $n=8$ animals. Scale bars, $50 \mu \mathrm{m}$. $\boldsymbol{B}$, Inputoutput curves of the fEPSP slope of MPP-granule cell synapses in vivo. PS depressed the synaptic responses of granule cells. Insets show representative traces of fEPSP (left, control; right, $P S) .{ }^{*} p<0.05$ versus controls; tw0-way repeated-measures ANOVA, $F_{(1,135)}=6.10 . n=$ 8-9 animals. C, Scatter plots showing LTP induced by TBS of MPP. Insets show representative traces of fEPSP (left, control; right, PS) before (solid) and after (dotted) TBS. ${ }^{*} p<0.05$ versus controls; two-way repeated-measures ANOVA, $F_{(1,406)}=5.52 . n=8-9$ animals. Values represent means \pm SEM.

ethyl ether (Wako Pure Chemicals) and perfused transcardially with cold PBS, followed by $4 \%$ paraformaldehyde. Brain samples were postfixed with $4 \%$ PFA at $4^{\circ} \mathrm{C}$ for $24 \mathrm{~h}$. Two hundred or $300 \mu \mathrm{m}$ sections were prepared with a Zero-1 vibratome (Dosaka).

Immunohistochemistry. Immunohistochemical staining was performed as follows except the staining for mineralocorticoid receptors, which is described later.

Fixed hippocampal slices were treated with $0.3 \%$ Triton X-100 for $12 \mathrm{~h}$. After a $1 \mathrm{~h}$ incubation in $5 \%$ goat serum at room temperature, primary antibodies in PBS containing $2 \%$ goat serum were applied at $4{ }^{\circ} \mathrm{C}$ for $24 \mathrm{~h}$, followed by incubation with secondary antibodies for $4 \mathrm{~h}$. For BrdU detection, these steps were followed by DNA denaturation in $2 \mathrm{~N}$ $\mathrm{HCl}$ for $20 \mathrm{~min}$ at $37^{\circ} \mathrm{C}$. Afterward, sections were rinsed in $0.1 \mathrm{M}$ borate buffer, $\mathrm{pH}$ 8.4. The primary antibodies were applied at the following concentrations: rabbit anti-GFP (1:1000; Invitrogen), mouse anti-BrdU
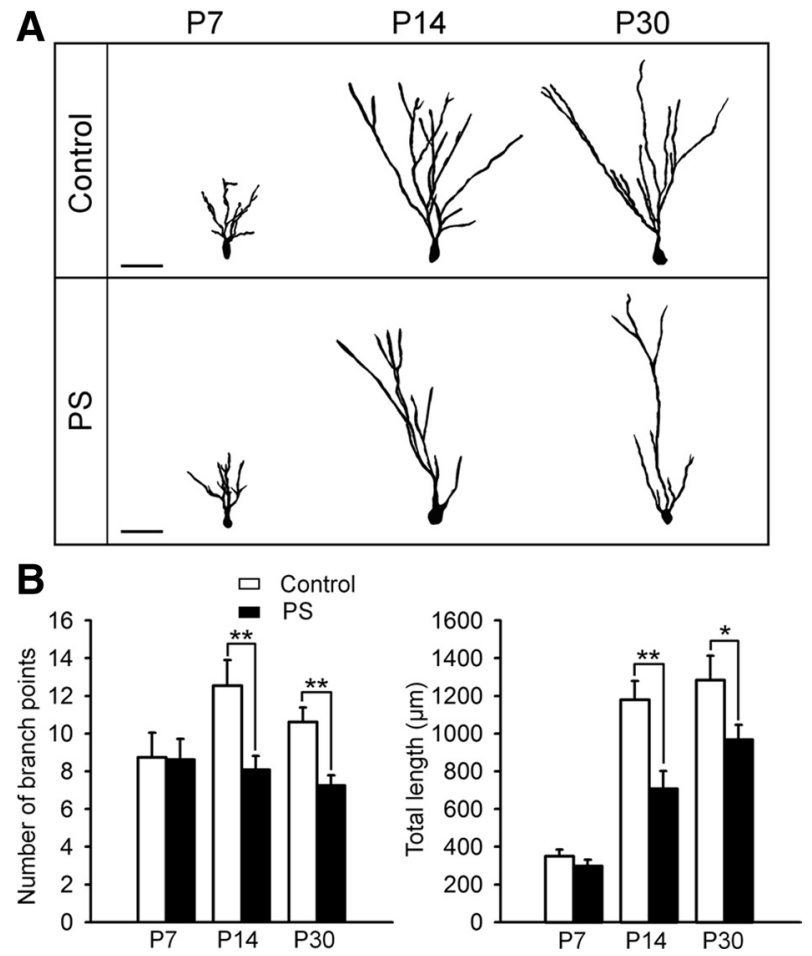

Figure 3. PS-induced malformation of granule cell dendrites appears from P14.A, Tracing of granule cell dendrites at P7, P14, and P30. Scale bar, $50 \mu \mathrm{m}$. B, Quantification of the number of branch points and the total length. ${ }^{*} p<0.05,{ }^{* *} p<0.01$ versus controls; Student's $t$ test or Mann-Whitney $U$ test. $n=8-12$ cells from 3 to 4 animals. Values represent means \pm SEM.

(1:1000; Sigma), rat anti-BrdU (1:1000; AbD Serotec), mouse anti-Prox 1 (1:2000; Millipore), mouse anti-glucocorticoid receptor (1:200; Abcam), rabbit anti-ZsGreen (1:200; Clontech), and mouse anti-MAP2 (1:1000; Millipore Bioscience Research Reagents). The secondary antibodies used were as follows: goat anti-rabbit Alexa Fluor 488 (1:500), goat antimouse Alexa Fluor 594 (1:500), donkey anti-goat Alexa Fluor 594 (1: 500), donkey anti-mouse Alexa Fluor 594 (1:500), and rabbit anti-goat Alexa Fluor 488 (1:500; Invitrogen). Some samples were incubated with Neurotrace fluorescent Nissl (1:100; Invitrogen) during incubation with the secondary antibodies.

To immunostain mineralocorticoid receptors, fixed slices were permeabilized with $0.1 \%$ Triton X-100 and $1 \%$ donkey serum for $10 \mathrm{~min}$. Subsequently, the samples were incubated with goat anti-mineralocorticoid receptor (1:50; Santa Cruz Biotechnology) in PBS containing $0.1 \%$ Triton $\mathrm{X}-100$ and $1 \%$ donkey serum for $12 \mathrm{~h}$ at room temperature. Next, the samples were incubated with donkey anti-goat Alexa Fluor 488 (1:500; Invitrogen) for $3 \mathrm{~h}$ at room temperature. These steps were subsequently followed by BrdU immunostaining to detect mineralocorticoid receptors and BrdU in the same samples, because mineralocorticoid receptor expression pattern was altered when DNA denaturation in $\mathrm{HCl}$ was performed before mineralocorticoid receptor immunostaining (data not shown). After being washed extensively in PBS, the samples were incubated in $2 \mathrm{~N} \mathrm{HCl}$ for $10 \mathrm{~min}$ at $60^{\circ} \mathrm{C}$. Subsequently, they were rinsed in $0.1 \mathrm{~m}$ borate buffer, $\mathrm{pH}$ 8.4. Then the samples were permeabilized with $0.1 \%$ Triton X-100 and $1 \%$ donkey serum for $10 \mathrm{~min}$. After the permeabilization, the samples were incubated with rat anti-BrdU (1:1000) in PBS containing $0.1 \%$ Triton X-100 and $1 \%$ donkey serum for $12 \mathrm{~h}$ at room temperature. Finally, the samples were incubated with donkey anti-rat Alexa Fluor 594 for $3 \mathrm{~h}$ at room temperature.

For double staining of polysialic acid (PSA) and mineralocorticoid receptor, fixed slices were permeabilized with $0.1 \%$ Triton X-100 and 5\% horse serum for $10 \mathrm{~min}$. Subsequently, the samples were incubated with goat anti-mineralocorticoid receptor (1:50) and mouse IgM anti-PSA (12E3) (Seki and Arai, 1991, 1993) (1:2000; a generous gift from Dr. Seki, Tokyo Medical University, Tokyo, Japan) in PBS containing $0.1 \%$ Triton 
X-100 and 5\% horse serum at room temperature for $12 \mathrm{~h}$. Next, the samples were incubated with rabbit anti-goat Alexa Fluor 488 (1:500) for $3 \mathrm{~h}$. After extensive washing, the samples were incubated with goat anti-mouse IgM Alexa Fluor 594 (1:500) for $3 \mathrm{~h}$.

Fluorescence signals were observed using an MRC-1024 confocal imaging system (Bio-Rad) with a $20 \times(\mathrm{NA}, 0.75)$ and a $60 \times(\mathrm{NA}, 1.20)$ objective (Nikon) or an FV-1000 confocal imaging system (Olympus) with a $20 \times(\mathrm{NA}, 0.95) \mathrm{ob}-$ jective (Olympus). Corticosterone receptor levels in newborn granule cells were measured by analyzing the immunofluorescence intensity of these receptors in BrdU-positive cells and PSA-positive cells. We measured the immunofluorescence intensity of mineralocorticoid receptor within a cytoplasmic area along the nuclei of BrdU-positive cells or PSA-positive cells. The average intensities were quantified in 20 randomly selected BrdUpositive cells or PSA-positive cells from each of four subregions (i.e., 80 cells total) of the granule cell layer, including suprapyramidal and infrapyramidal blade in either dorsal or ventral portions of the hippocampus. For each slice, the background fluorescence was obtained from five adjacent $20 \times 20 \mu \mathrm{m}^{2}$ areas outside the slice. The values for the background intensity were averaged, and the intensity was expressed as (intensity of the granule cell layer - background intensity)/ background intensity. Finally, the fluorescence intensity was normalized by the value in the suprapyramidal granule cell layer of the dorsal hippocampus in P14 control rats. The density of MAP2-positive processes in the molecular layer was measured by averaging the total length of MAP2-positive processes in $50 \mu \mathrm{m}$ (length) $\times 50$ $\mu \mathrm{m}$ (width) $\times 20 \mu \mathrm{m}$ (depth) cubes. For this analysis, 10 cubes/slice were placed in each subregion of the molecular layer, i.e., the outer, middle, and inner molecular layers.

Confocal time-lapse imaging of granule cells. Time-lapse imaging of mYFP-positive granule cells in cultured slices was performed every $24 \mathrm{~h}$ during the 5-7 and 12-14 d in vitro (DIV) periods using an MRC-1024 confocal imaging system with a $20 \times$ objective (Nakahara et al., 2009). Each confocal image was captured within $5 \mathrm{~min}$ in a sterilized chamber filled with the culture medium $\left(37^{\circ} \mathrm{C}, 5 \% \mathrm{CO}_{2}\right.$, and $95 \%$ room air in the atmosphere) in which the samples were placed. After imaging, the samples were immediately returned to the incubator. Images obtained in the time-lapse study were analyzed using NIH ImageJ. Branches that did not exist on the previous day but were newly added were designated as added branches. Branches that existed on the previous day but disappeared were designated as lost branches.

In vivo electrophysiology. Eight- to 11-weekold rats were anesthetized with $1.5 \mathrm{~g} / \mathrm{kg}$ urethane (Wako Pure Chemicals) delivered intraperitoneally and placed in a stereotaxic head holder. Two bipolar stimulating electrodes (thin stainless-steel needles coated with epoxy resin except the $60 \mu \mathrm{m}$ tip) were placed on the MPP ( $8.0 \mathrm{~mm}$ posterior and $4.1 \mathrm{~mm}$ lateral to bregma), and a tungsten recording electrode (FHC) was inserted into the granule cell layer (3.4 $\mathrm{mm}$ posterior and $2.5 \mathrm{~mm}$ lateral to bregma) to record the field EPSPs

C

D $20 \mu \mathrm{m}$.

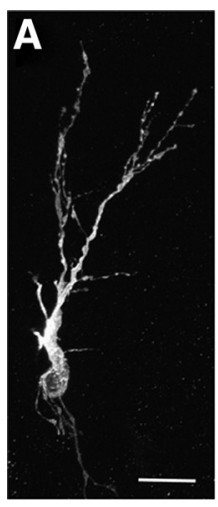

B
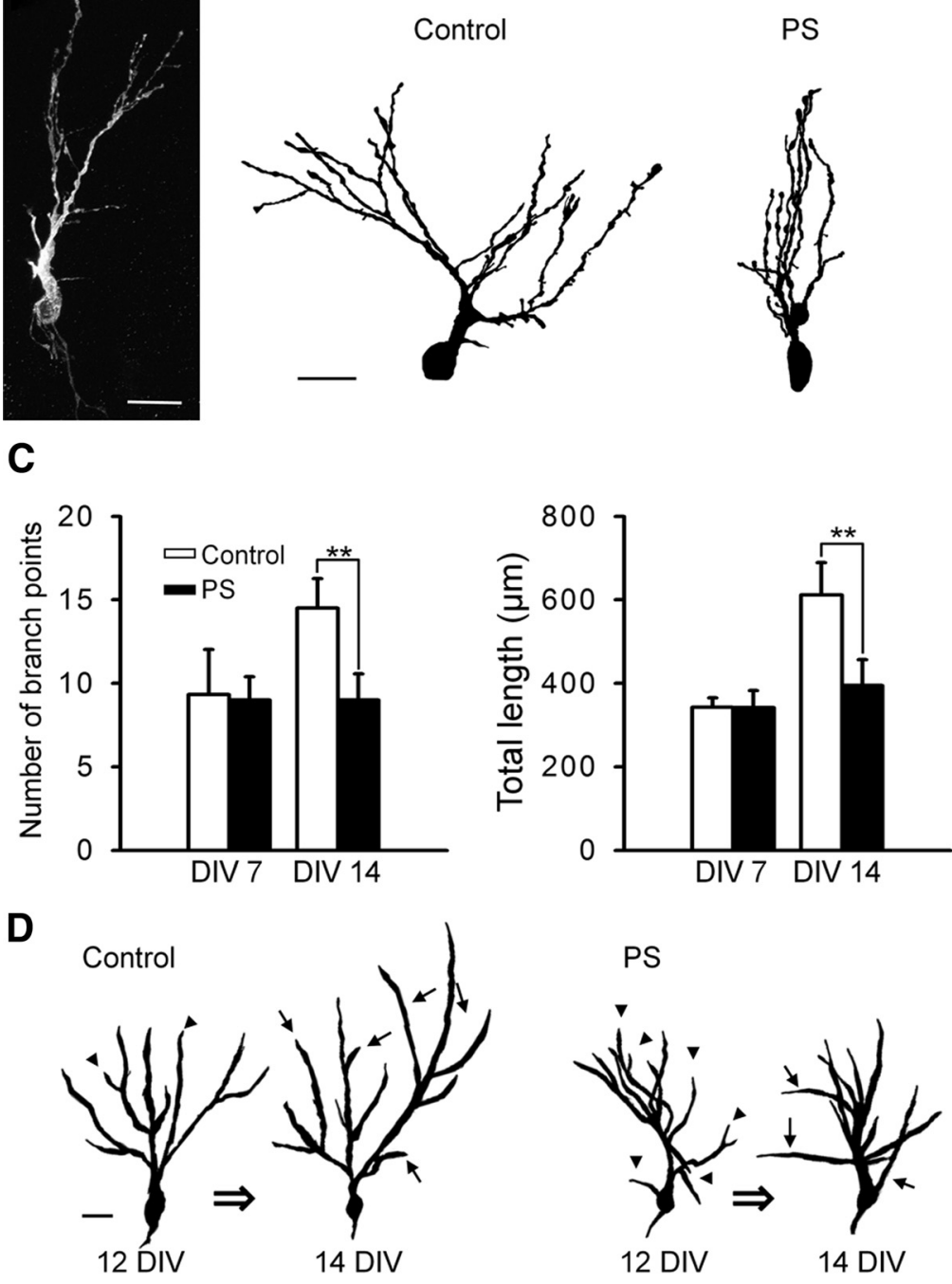

PS
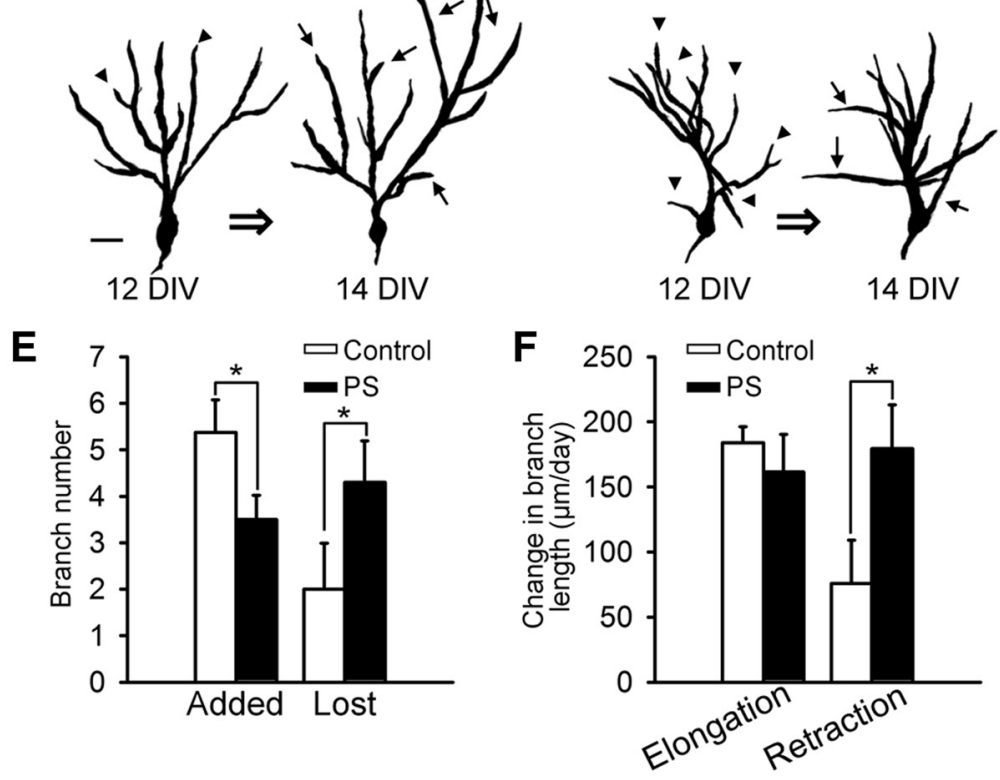

Figure 4. PS inhibits dendritic maturation in vitro. $A$, A representative image of an $\mathrm{MYFP}$-expressing granule cell from a cultured hippocampal slice. $B$, Representative granule cells at 14 DIV obtained from control and PS rats. C, Quantification of the number of branch points and the total length of granule cell dendrites. PS significantly decreased the number of branch points and total length at 14 DIV but not at 7 DIV. ${ }^{* *} p<0.01$ versus DIV-matched control granule cells; Student's $t$ test or Mann-Whitney $U$ test. $n=$ $11-12$ cells from four independent experiments. Scale bar, $20 \mu \mathrm{m}$. D, Branch dynamics during 12-14 DIV. Arrows indicate added branches, and arrowheads indicate lost branches. $E$, PS significantly decreased the number of added branches and increased the number of lost branches. $\boldsymbol{F}$, Changes in the length of elongating and retracting branches. ${ }^{*} p 0.05$ versus control cells; Student's $t$ test or Mann-Whitney $U$ test. $n=8-10$ cells from 4 to 5 independent experiments. Values represent means \pm SEM. Scale bar,

(fEPSPs). Single-pulse test stimuli (100 $\mu$ s duration) were applied to the MPP at an interval of $30 \mathrm{~s}$. The intensity of the stimulus was adjusted to produce an fEPSP with a slope that was $50 \%$ of the maximum. To induce long-term potentiation (LTP) at MPP-granule cell synapses, theta-burst 
A

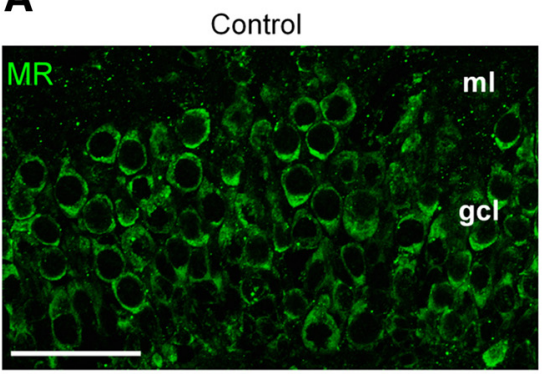

C

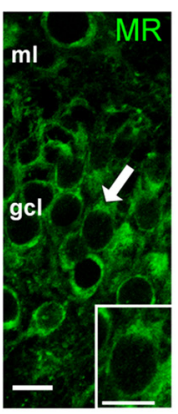

Control

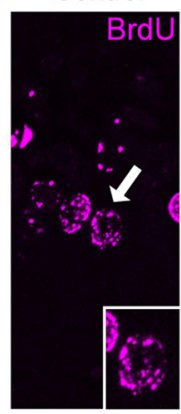

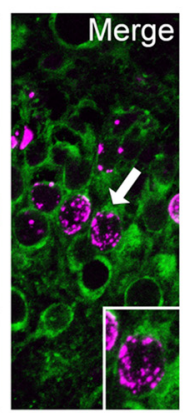

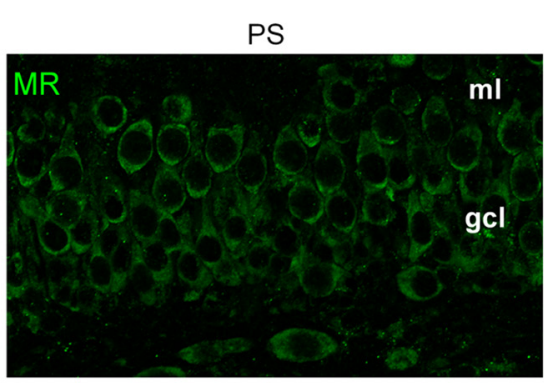

B

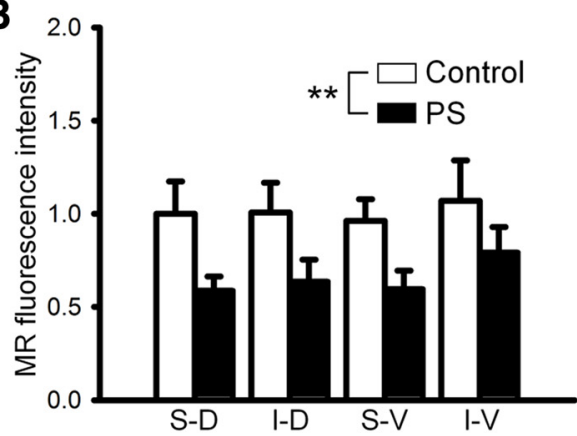

Figure 5. PS downregulates the expression of mineralocorticoid receptor in neonatal-generated granule cells. $\boldsymbol{A}$, Immunohistochemical staining of mineralocorticoid receptor (green) in the granule cell layer of P14 rats. B, Quantification of immunofluorescence intensity of mineralocorticoid receptor in different anatomical locations in P14 rats (S-D, suprapyramidal granule cell layer in dorsal hippocampus; I-D, infrapyramidal granule cell layer in dorsal hippocampus; S-V, suprapyramidal granule cell layer in ventral hippocampus; I-V, infrapyramidal granule cell layer in ventral hippocampus). Values were normalized by the intensity in S-D area in control rats. ${ }^{* *} p<0.01$; two-way repeated-measures ANOVA, $F_{(1,12)}=12.43 . n=20$ cells per region from 3 animals. Values represent means \pm SEM. C, Immunohistochemical staining of BrdU (magenta) and mineralocorticoid receptor (green) at P14. Insets, High-magnification images of the BrdU-positive cells indicated by arrows. D, Quantification of immunofluorescence intensity of mineralocorticoid receptor in BrdU-positive cells in different anatomical locations in P14 rats. Values were normalized by the intensity in S-D area in control rats. ${ }^{*} p<0.05$; two-way repeated-measures ANOVA, $F_{(1,12)}=7.709 . n=20$ cells per region from 3 animals. Values represent means \pm SEM. Scale bars: $\boldsymbol{A}, 50 \mu \mathrm{m} ; \boldsymbol{C}, 10 \mu \mathrm{m}$.

stimulation (TBS), consisting of five bursts at $5 \mathrm{~Hz}$ and 20 pulses at 400 $\mathrm{Hz}$, was applied four times every $30 \mathrm{~s}$. The location of the electrode was verified by post hoc histological observation as described in a previous study (Nakao et al., 2004).

Forced swimming test. $\mathrm{P} 60$ rats were assessed in the forced swimming test. A modified version of the Porsolt test was used (Porsolt et al., 1978). On the pretest day, animals were individually plunged for $15 \mathrm{~min}$ into a plastic cylinder $(30 \mathrm{~cm}$ diameter, $50 \mathrm{~cm}$ height) containing water $19 \mathrm{~cm}$ high maintained at $23 \pm 1^{\circ} \mathrm{C}$. Animals were subsequently removed from water and dried in a heated cage before returning to their home cages. After $24 \mathrm{~h}$ (test day), rats were put back into the cylinder for $5 \mathrm{~min}$, and the duration of immobility (floating in the water with only the movements necessary to keep the head above water) was measured.

Blood collection and corticosterone measurement. Rats were killed between 2:00 P.M. and 4:00 P.M. Trunk blood was collected in heparinized tubes (Tozuka et al., 2009). The tubes were centrifuged at room temperature at $1000 \times \mathrm{g}$, and the plasma was separated and stored at $-80^{\circ} \mathrm{C}$ until use. To determine the concentration of corticosterone, plasma was extracted with dimethyl chloride. Then, the extract was evaporated and the residue was suspended for hormone evaluation using a commercial enzyme immunoassay kit (Cayman Chemicals).

Statistical analysis. The data are represented as means \pm SEM. The Mann-Whitney $U$ test or Steel test was used for nonparametric statistics, whereas Student's $t$ test or Dunnett's test after ANOVA was used for parametric statistics. Two-way ANOVA or two-way repeated-measures ANOVA was used for statistical analysis of body weight, corticosterone levels, receptor expression, and synaptic plasticity.

\section{Results}

PS attenuates the maturation of dentate granule cells

To explore the effects of PS on morphological and functional development of the hippocampus in offspring, pregnant mothers received daily restraint stress during late gestation (see Materials and Methods). This procedure induced a slight reduction in the body weight at P14 and depressive-like behavior in adulthood, i.e., the immobility time in the forced swimming test was increased in PS rats (control, $121.3 \pm 7.3 \mathrm{~s}$; PS, $143.5 \pm 5.0 \mathrm{~s} ; p<$ 0.05 between control and PS; Student's $t$ test, $n=7-10$ ), which is in agreement with previous studies (Morley-Fletcher et al., 2003; Abe et al., 2007).

To examine the effects of PS on granule cell maturation, we injected a retroviral vector encoding mYFP into the dentate gyrus at P0, because most of the granule cells in adulthood are born during the early postnatal periods (Muramatsu et al., 2007). At P60, mYFP-expressing cells that were positive for the granule cell marker Proxl were found in the granule cell layer (Fig. $1 A$ ). The granule cells possessed a significantly decreased number of branch points and total dendritic length in PS rats (Fig. $1 B, C$ ). The reduction of dendritic branches (Fig. $1 D$ ) and spine density (Fig. $1 E$ ) were prominent in the middle molecular layer.

Next, to examine how long the effect of PS on dendritic morphogenesis persists in subsequent generation of granule cells, we examined the total length of mature dendrites in the molecular layer at $\mathrm{P} 60$ by performing immunohistochemistry using the mature dendritic marker MAP2. The density of MAP2-positive processes in PS rats was reduced in the middle and the outer molecular layers, suggesting that the effect of PS is continuous (Fig. 2A). In agreement with this, the fEPSP slope evoked by the stimulation of MPP, which innervates the middle molecular layer, was depressed in the granule cells of PS rats (Fig. $2 \mathrm{~B}$ ). To further establish the effects of PS on synaptic transmission, LTP 
was induced by the TBS of MPP. The MPP-induced increase in fEPSP lasted at least $60 \mathrm{~min}$ in control rats but not in PS rats (control, $12.7 \pm 2.20 \%$; PS, $3.43 \pm$ 7.07\%) (Fig. 2C). These results indicate that PS attenuates both morphological and functional maturation of granule cell dendrites in adulthood.

To determine the exact time point when PS affects dendritic maturation, we analyzed the morphology of dendrites at P7, P14, and P30 (Fig. 3A), finding that dendritic malformation appeared after P14 (Fig. 3B). Next, we investigated which step in dendritic maturation was affected by PS, using hippocampal slice cultures prepared from either control or PS rats (Fig. 4). The granule cell dendrites in cultured slices were visualized by injecting mYFP-encoding retroviruses into the granule cell layer at 0 DIV (Fig. $4 A$ ). We found that PS-induced dendritic malformation was maintained in vitro at 14 DIV but not at 7 DIV, in agreement with our in vivo findings (Fig. $4 B, C$ ). The time-lapse confocal analysis of cultured slices during 12-14 DIV revealed that the number of added branches was decreased, whereas that of lost branches was increased in PS cultures (Fig. $4 D, E$ ). In addition, PS significantly increased the length of retracting branches (Fig. 4F). We also confirmed that these phenomena were not observed until 7 DIV (data not shown). These results explain the time window between PS and the morphological changes observed in granule cells in vivo: dendritic malformation appeared at P14 but not at P7.

\section{PS downregulates the expression of mineralocorticoid receptors}

We next examined the possible involvement of corticosteroid receptors in PS-induced deficits in dendritic maturation of granule cells. Corticosteroids are a well-known class of stress hormones. A great variety of stressors increase plasma corticosteroid hormone levels by activating the HPA axis (de Kloet et al., 2005). Thus, it is possible that excessive corticosteroid hormones transferred from the stressed mother affect the expression of corticosteroid hormone receptors in their offspring. There are two corticosteroid hormone receptors: the high-affinity mineralocorticoid receptors and the low-affinity glucocorticoid receptors (Reul and de Kloet, 1985). Because both receptors are known to be expressed in granule cells (Han et al., 2005), we investigated whether PS affects the expression of these two receptors in offspring.

First, we found that PS induced a significant decrease in the expression levels of mineralocorticoid receptors by measuring randomly selected 20 granule cells in four subregions of the granule cell layer, i.e., the suprapyramidal and infrapyramidal blade of the granule cell layer in both dorsal and ventral hippocampus at P14 (Fig. $5 A, B$ ). Next, to examine the consequences of PS on the expression levels of mineralocorticoid receptors in neonatalgenerated granule cells, we injected BrdU, an S-phase marker,
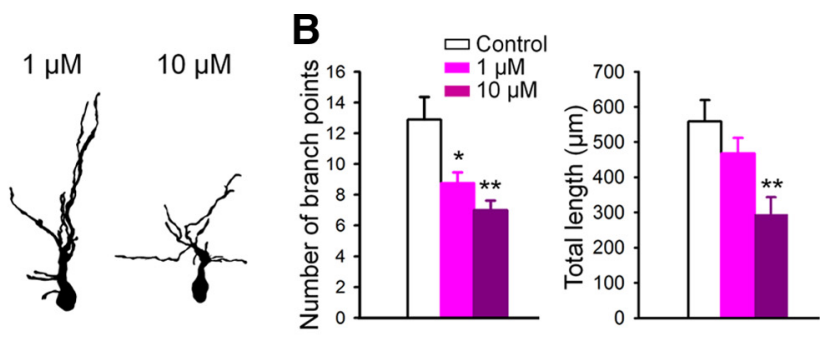

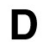

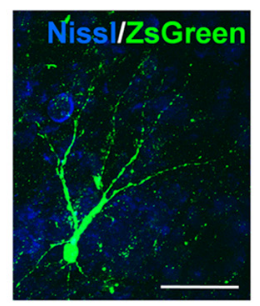

promoter ZsGreen
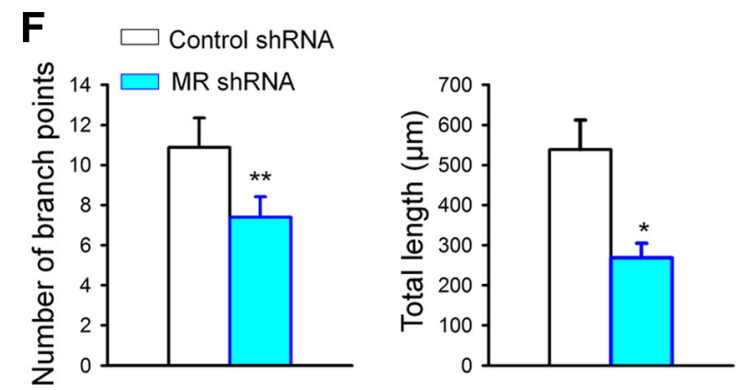

Figure 6. Mineralocorticoid receptor signaling is required for dendritic maturation in vitro. $\boldsymbol{A}$, Tracings of $\mathrm{m} Y F P$-expressing granule cells at 14DIV. Spironolactone (1 or $10 \mu \mathrm{m}$ ) was chronically applied to the culture medium. B, Quantification of the number of branch points and total length. ${ }^{*} p<0.05,{ }^{* *} p<0.01$ versus controls; Dunnett's test or Steel test. $n=9-12$ cells from 3 to 4 independent experiments. $\boldsymbol{C}$ ocorticoid receptor. $\boldsymbol{E}$, Tracing of ZsGreen-expressing granule cells. $\boldsymbol{F}$, Quantification of the number of branch points and total length Values represent means \pm SEM. Scale bars: $\boldsymbol{A}, \boldsymbol{E}, 20 \mu \mathrm{m} ; \boldsymbol{D}, 50 \mu \mathrm{m}$. MR, Mineralocorticoid receptor.

into P0 rats. The expression of mineralocorticoid receptors in BrdU-positive cells was significantly lower in all the subregions in PS rats (Fig. 5C,D), whereas there was no significant difference in the expression of glucocorticoid receptors between control and PS rats (supplemental Fig. S1, available at www.jneurosci.org as supplemental material). The difference of subregions did not affect the expression levels of both mineralocorticoid receptors (Fig. $5 D)(p>0.05$; two-way repeated-measures ANOVA, $F_{(3,12)}=2.647 ; n=20$ cells per region) and glucocorticoid receptors (supplemental Fig. S1 $B$, available at www.jneurosci.org as supplemental material) ( $p>0.05$; two-way repeated-measures ANOVA, $F_{(3,12)}=0.4162 ; n=20$ cells per region).

To further confirm that PS downregulates mineralocorticoid receptors in the immature granule cells, the expression level of mineralocorticoid receptors was immunohistochemically analyzed in the granule cells that were immunopositive for PSA, a marker for immature granule cells (Seki and Arai, 1993). We found that the expression of mineralocorticoid receptors in PSApositive cells was significantly lower in PS rats (supplemental Fig. $\mathrm{S} 2$, available at www.jneurosci.org as supplemental material), in agreement with that in BrdU-positive cells (Fig. 5C,D). The difference of subregions did not affect the expression levels of mineralocorticoid receptors (supplemental Fig. S2 B, available at www.jneurosci.org as supplemental material) $(p>0.05$; two-way repeated-measures ANOVA, $F_{(3,12)}=0.8359 ; n=20$ cells per region). 
A
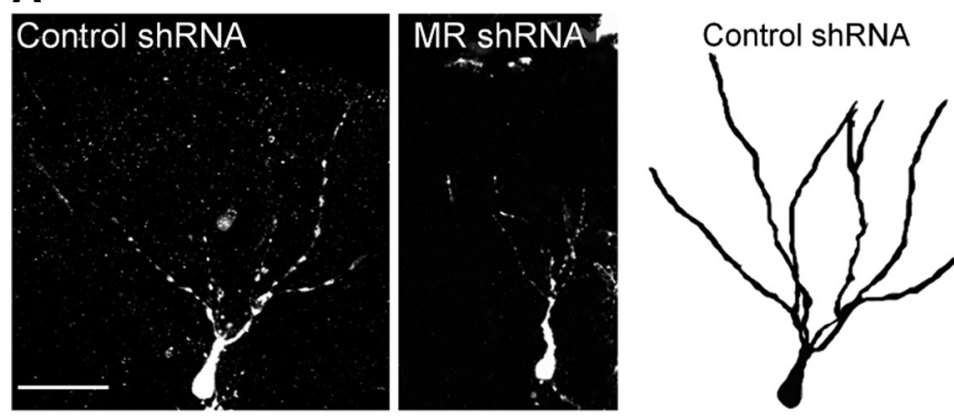

MR shRNA

B

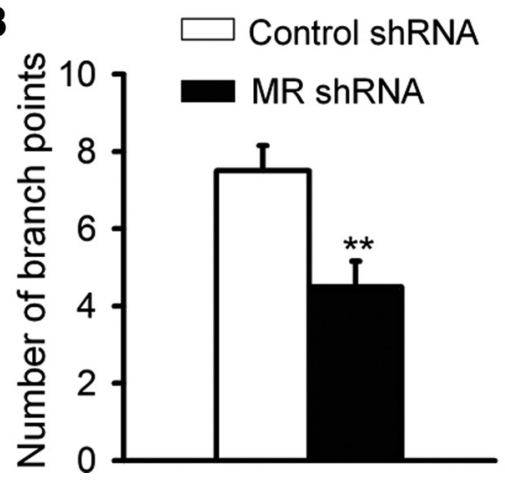

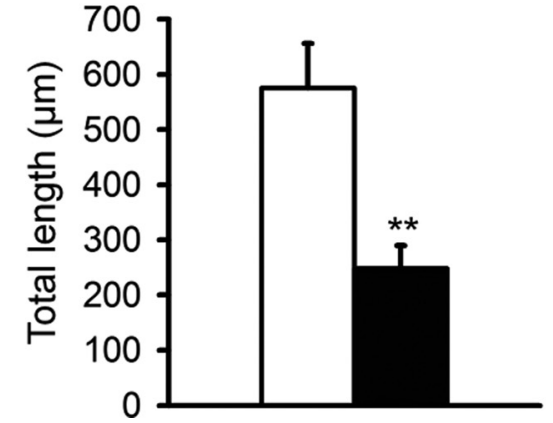

Figure 7. Mineralocorticoid receptor promotes dendritic maturation in vivo. $\boldsymbol{A}$, Confocal images of ZsGreen-expressing granule cells at P14. Tracings of the cells are shown at right. $\boldsymbol{B}$, The number of branch points and the total length were significantly decreased in MR shRNA-expressing cells. ${ }^{* *} p<0.01$ versus control shRNA; Student's $t$ test or Mann-Whitney $U$ test. $n=8$ cells from 3 animals. Values represent means \pm SEM. Scale bar, $50 \mu \mathrm{m}$.

Next, we examined whether PS-induced downregulation of mineralocorticoid receptors was long lasting. The fluorescence intensity of mineralocorticoid receptors in the suprapyramidal blade of granule cell layer, in which the morphology of granule cells were analyzed in this study, was measured at P7, P14, and P60. The expression of mineralocorticoid receptors was significantly reduced in PS rats at all the stages (supplemental Fig. S3, available at www.jneurosci.org as supplemental material). Downregulation of mineralocorticoid receptor was also detected in cultured hippocampal slices (supplemental Fig. S4, available at www.jneurosci.org as supplemental material). In control cultures, the expression of mineralocorticoid receptors in newborn granule cells gradually increased over time, whereas it stayed in the lower levels in PS cultures (supplemental Fig. S4B, available at www.jneurosci.org as supplemental material). These data indicate that the effect of PS is long lasting.

\section{Mineralocorticoid receptors are necessary for dendritic maturation}

To examine the role of mineralocorticoid receptors in dendritic maturation, we applied the mineralocorticoid receptor antagonist spironolactone ( 1 or $10 \mu \mathrm{M}$ ) to the cultured hippocampal slices, finding that spironolactone suppressed the dendritic maturation in a dose-dependent manner (Fig. 6A, $B$ ). To further confirm the role of mineralocorticoid receptors, they were knocked down in granule cells using retrovirus-mediated RNA interference. We injected retrovirus coexpressing MR shRNA and ZsGreen (Fig. 6C,D) into granule cells in cultured slices at 0 DIV. We confirmed that mineralocorticoid receptor expression was knocked down in MR shRNA-transfected granule cells compared with those transfected with control shRNA, using three-dimensional reconstruction of immunostained samples (supplemental Fig. S5, available at www.jneurosci.org as supplemental material).
After $14 \mathrm{~d}$, the dendritic maturation of MR-shRNA-expressing granule cells was attenuated compared with control (Fig. $6 E, F)$. We further confirmed the necessity of the mineralocorticoid receptor for dendritic maturation of granule cells in vivo. MR-shRNA-encoding retrovirus was injected into the dentate gyrus at P0. After $14 \mathrm{~d}$, the number of branch points and total length of dendrites were significantly decreased in MR-shRNA-expressing granule cells (Fig. $7 A, B$ ). These results suggest that the mineralocorticoid receptor promotes dendritic maturation of granule cells.

To elucidate whether PS-induced impairment of dendritic maturation results from the decreased activation of mineralocorticoid receptors, we pharmacologically activated mineralocorticoid receptors in the granule cells by chronically applying the agonists of mineralocorticoid receptor, fludrocortisone and aldosterone (Lan et al., 1982; Beaumont and Fanestil, 1983), respectively, to the media of slice cultures. Both reagents prevent PS-induced reduction of branch number and total length of the granule cell dendrites in a dosedependent manner, although fludrocortisone tended to be more effective than aldosterone in rescuing the total dendritic length (Fig. 8).

At the P0, P7, and P14 stages, there was no difference in basal levels of plasma corticosterone, a major corticosteroid hormone in rodents, between control and PS rat pups (17.30 \pm 3.10 and $20.55 \pm 3.36 \mathrm{ng} / \mathrm{ml}$ at $\mathrm{P} 0 ; 35.85 \pm 10.88$ and $34.50 \pm 9.64 \mathrm{ng} / \mathrm{ml}$ at $\mathrm{P} 7 ; 37.07 \pm 11.90$ and $24.22 \pm 7.60 \mathrm{ng} / \mathrm{ml}$ at $\mathrm{P} 14 ; p>0.05$ between control and PS; two-way ANOVA, $F_{(1,36)}=0.2536 ; n=$ 5-8 animals.). These results indicate that the downregulation of mineralocorticoid receptors, but not changes in plasma corticosterone, are the primary mechanism of PS-induced deficits in the dendritic maturation of granule cells.

\section{PS attenuates dendritic maturation in both genders}

The results above are obtained from female offspring. We also confirmed that PS induced almost the same effects in adult male offspring, such as dendritic malformation and depressed synaptic responses (Fig. 9), and the increased immobility time in the forced swimming test was increased in PS rats (control, $126.3 \pm$ $4.0 \mathrm{~s}$; PS, $161.0 \pm 4.4 \mathrm{~s} ; p<0.05$ between control and PS; Student's $t$ test; $n=7-10)$. In addition, both spironolactone and MR shRNA inhibited dendritic maturation of granule cells in male offspring (Fig. 10). However, the timing of PS-induced effects on dendritic maturation showed a gender difference. Unlike in females, the decrease in branch points was not observed until P14 in males (Fig. 11), consistent with a delayed decrease of mineralocorticoid receptor expression in PS male rats (supplemental Fig. S6, available at www.jneurosci.org as supplemental material). These data suggest that the effects of PS appear later in males than in females.

\section{Discussion}

Our study illuminates the effects of PS on postnatal-generated granule cells that survive into adulthood and is distinct from 
A

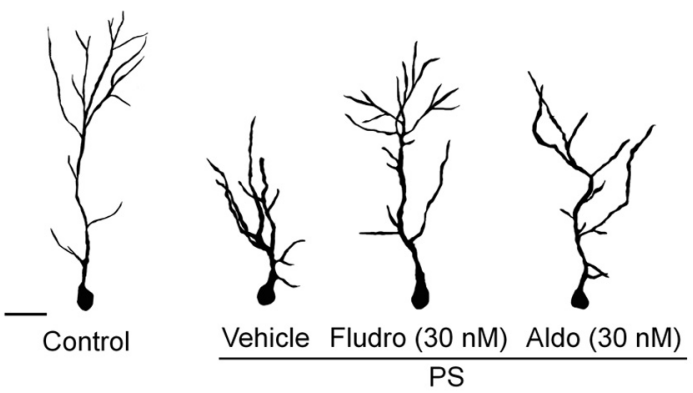

B
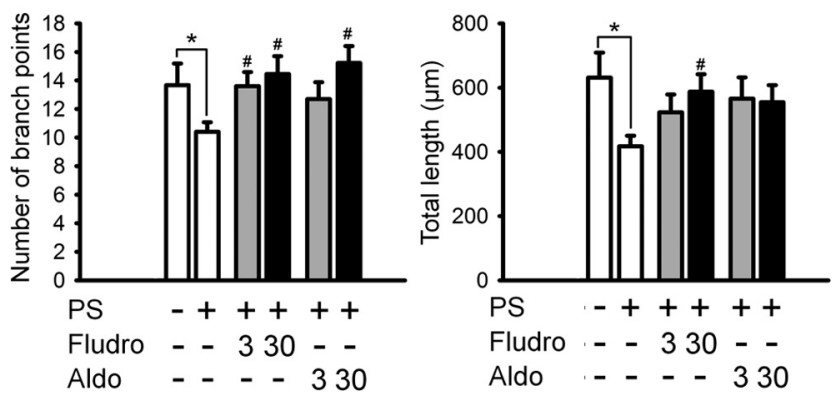

Figure 8. Pharmacological activation of mineralocorticoid receptors prevents PS-induced impairment of granule cell maturation. $A$, Tracings of mYFP-expressing granule cells at $14 \mathrm{DIV}$. Fludrocortisone (Fludro) or aldosterone (Aldo) was applied to the culture medium from 0 to 14 DIV. $\boldsymbol{B}$, Quantification of the number of branch points and total length of granule cell dendrites. Numerical values under figures indicate concentration of drugs (nanomoles). ${ }^{*} p<0.05$ versus controls, Student's $t$ test or Mann-Whitney $U$ test; ${ }^{\#} p<0.05$ versus vehicle treatment in PS, Dunnett's test or Steel test. $n=9-10$ cells from 2 independent experiments. Values represent means \pm SEM. Scale bars, $10 \mu \mathrm{m}$.

previous studies that examined the effects of PS on prenatally born neurons such as hippocampal pyramidal cells and prefrontal pyramidal cells (Michelsen et al., 2007; Martínez-Téllez et al., 2009). Furthermore, we first revealed the molecular mechanism underlying PS-induced dendritic impairment, i.e., the downregulation of mineralocorticoid receptors.

The decrease in maternal care in the postnatal stages affects neuronal maturation in the cortex and the locus ceruleus (Pinkernelle et al., 2009; Swinny et al., 2010). Given that PS has been reported to influence maternal care (Meek et al., 2001; Champagne and Meaney, 2006), it is possible that PS indirectly reduced the dendritic complexity of granule cells in offspring by decreasing maternal care. However, considering that the effects of PS were maintained in cultured slices (Fig. 4), it is likely that the effects of PS are independent of maternal care. The present study cannot completely exclude the possibility that the reduction in body weight is associated with the dendritic malformation because malnutrition is known to affect maturation of granule cell dendrites (Andrade et al., 2002); however, considering that MR shRNA alone induced the dendritic malformation in vitro (Figs. 6, 10) and in vivo (Figs. 7, 10) without affecting the body weight of animals (data not shown), the reduction of MR expression after PS is likely to play a critical role in the dendritic malformation in adulthood.

PS persistently decreased expression of mineralocorticoid receptors (supplemental Figs. S3, S4, S6, available at www. jneurosci.org as supplemental material). One possible cause for this phenomenon is the high corticosterone levels induced by PS, because excessive plasma corticosterone is transferred from pregnant mothers to fetuses through the placenta (Seckl, 2004) and may downregulate the expression of mineralocorticoid receptors.
A

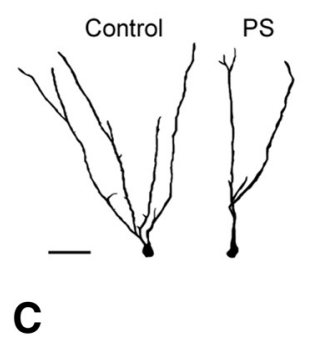

B
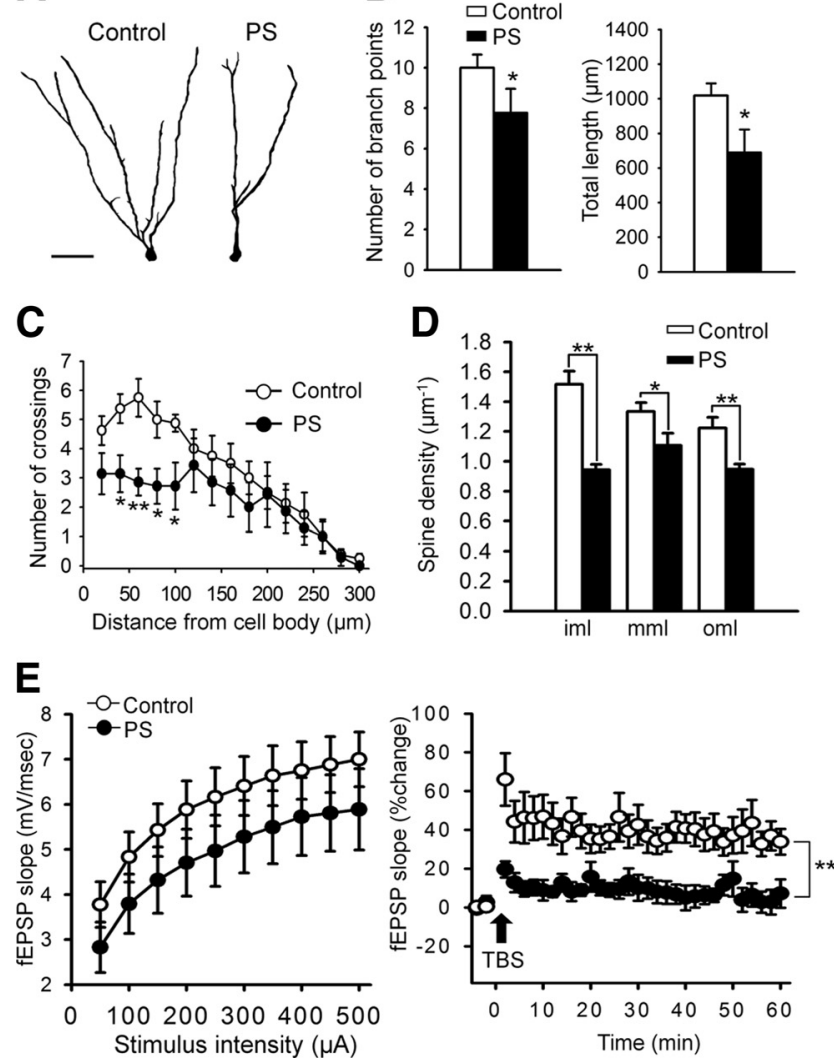

Figure 9. PS attenuates dendritic complexity and depresses synaptic responses of granule cells in male rats. $\boldsymbol{A}$, Representative granule cells obtained from control and PS rats. $\boldsymbol{B}$, PS significantly decreased the number of branch points and the total length of granule cell dendrites. $C$, Sholl analysis of granule cell dendrites. ${ }^{*} p<0.05,{ }^{* *} p<0.01$ versus control; Student's t test. $n=9$ cells from 3 to 4 animals. $\boldsymbol{D}$, Quantification of spine density of granule cell dendrites. iml, Inner molecular layer; $\mathrm{mml}$, middle molecular layer; oml, outer molecular layer. ${ }^{*} p<0.05,{ }^{* *} p<0.01$ versus control; Student's $t$ test. $n=7-10$ cells from 3 to 4 animals. E, Left, Input- output curves offEPSP slope in MPP-granule cell synapses in vivo. Right, Scatter plots of LTP induced by TBS of MPP. ${ }^{* *} p<0.01$ versus control; two-way repeated-measures ANOVA, $F_{(1,406)}=10.80 . n=7-11$ animals. Values represent means \pm SEM. Scale bar, $50 \mu \mathrm{m}$.

This possibility is supported by the finding that extremely high doses of corticosterone decrease mineralocorticoid receptor mRNA in the hippocampus (Hügin-Flores et al., 2004).

The timing of PS-induced reduction of mineralocorticoid receptor expression was delayed in males (supplemental Fig. S6, available at www.jneurosci.org as supplemental material) compared with females (supplemental Figs. S3, S4, available at www. jneurosci.org as supplemental material). Although the mechanisms underlying these gender differences remain unclear, some reports have shown that sex hormones, such as androgens and estrogens, regulate the expression of certain genes, including those encoding glucocorticoid receptors and corticotrophin-releasing factor (Kerr et al., 1996; Patchev and Almeida, 1996).

PS did not affect expression of glucocorticoid receptors (supplemental Fig. S1, available at www.jneurosci.org as supplemental material). Corticosterone binds to both mineralocorticoid and glucocorticoid receptors, displaying a 10-fold higher affinity for mineralocorticoid receptors (Reul and de Kloet, 1985). This suggests that a mild stressor, such as restraint stress in this study, more robustly affects the expression of mineralocorticoid receptors than of glucocorticoid receptors.

Our pharmacological and genetic approaches revealed that the mineralocorticoid receptor is required for proper dendritic 
A

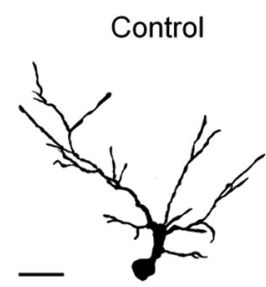

\section{C in vitro}

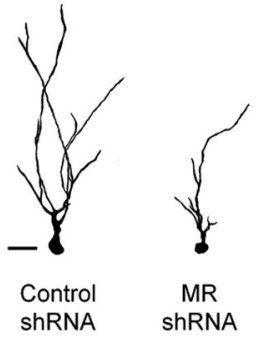

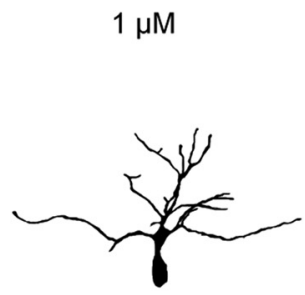

$\square$ Control shRNA

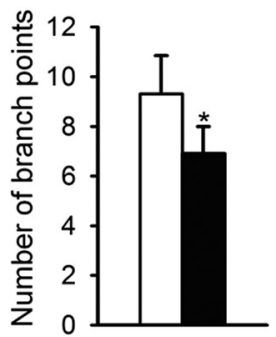

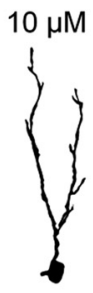

MR ShRNA

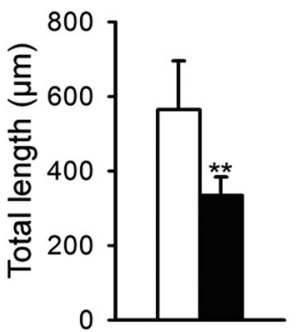

B
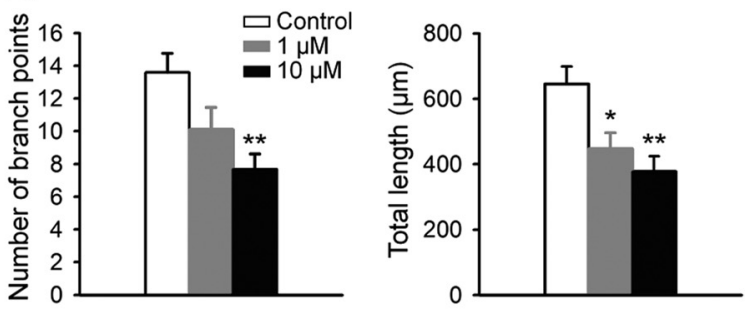

D in vivo

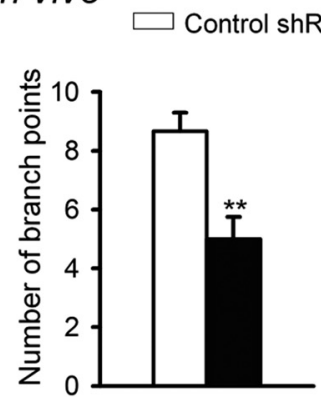

MR ShRNA

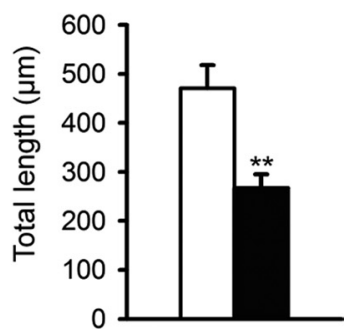

Figure 10. Mineralocorticoid receptor promotes dendritic maturation of granule cells in males as well as females. $A, m Y F P$-expressing granule cells in control and spironolactone (1 and $10 \mu \mathrm{m}$ )-treated slices. $\boldsymbol{B}$, Quantification of the number of branch points and total length. ${ }^{*} p<0.05,{ }^{* *} p<0.01$ versus controls; Tukey's test or Steel-Dwass test. $n=9-10$ cells from 3 to 4 independent experiments. C, Tracings of ZsGreen-expressing cells in cultured slices. Right, Quantification of the number of branch points and total length. ${ }^{*} p<0.05,{ }^{* *} p<0.01$ versus control shRNA; Student's $t$ test or Mann-Whitney $U$ test. $n=10$ cells from 3 independent experiments. $\boldsymbol{D}$, The number of branch points and total length were significantly decreased in MR shRNA-expressing cells in P14 rats. ${ }^{* *} p<0.01$ versus control shRNA; Student's $t$ test or Mann-Whitney $U$ test. $n=4-8$ cells from 3 animals. Values represent means \pm SEM. Scale bars, $20 \mu \mathrm{m}$.
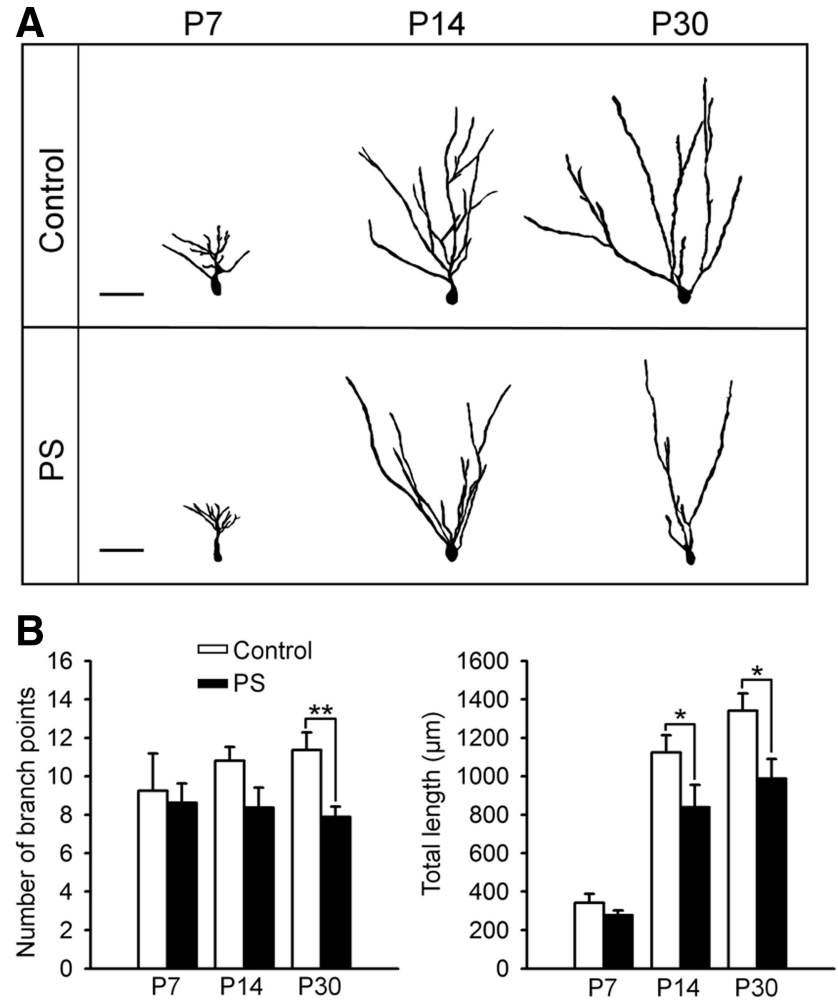

Figure 11. PS-induced decrease in dendritic arborization is slightly delayed in male compared with female. A, Tracing of granule cell dendrites at P7, P14, and P30. B, Quantification of the number of branch points and the total length of granule cell dendrites. The number of branch points significantly decreased at P30 but not P7 or P14. ${ }^{*} p<0.05$, ${ }^{* *} p<0.01$ versus age-matched control; Student's $t$ test or Mann-Whitney $U$ test. $n=$ $9-11$ cells from 3 animals. Values represent means \pm SEM. Scale bars, $50 \mu \mathrm{m}$. maturation of granule cells (Figs. 6, 10). We further demonstrated that the pharmacological activation of mineralocorticoid receptors rescued the PS-induced dendritic impairment (Fig. 8), which suggests that the mineralocorticoid receptor is a possible molecular determinant of detrimental effects of PS on granule cell maturation. Although mineralocorticoid receptors are generally considered to be primarily occupied by endogenous corticosterone, pharmacological agents likely activated unoccupied receptors and exerted protective effects on granule cell maturation. In support of this hypothesis, it has been demonstrated that the application of aldosterone to hippocampal slices reversed LTP impairment at MPP-granule cell synapses in diabetic rats that showed high levels of serum corticosterone (Stranahan et al., 2010).

Mineralocorticoid receptor is a nuclear receptor that regulates gene transcription, thereby controlling the development, homeostasis, and metabolism of the organism (Yang and Young, 2009). Therefore, it is possible that mineralocorticoid receptors control the expression of certain genes that are related to modulation of the cytoskeleton, resulting in regulation of branch formation and neurite elongation. However, little is known about the candidate genes regulated by mineralocorticoid receptors in the brain (Joëls et al., 2008). Thus, additional studies are required to reveal the mechanisms underlying mineralocorticoid receptor-induced dendritic maturation.

PS decreased synaptic responses and the plasticity of granule cell dendrites in response to MPP stimulation (Figs. 2, 9). Although some stressors in adulthood depress LTP in granule cells (Joëls, 2007), there have been no reports examining the longlasting effects of PS on LTP of MPP-granule cell synapses. Because granule cells serve a crucial role in associative memory (Morris, 2006; Kesner, 2007) and are involved in certain affective disorders (Santarelli et al., 2003), PS may persistently affect mem- 
ory and emotion via suppressed synaptic transmission to granule cells.

In conclusion, our study revealed that PS attenuates the dendritic maturation of granule cells through the downregulation of mineralocorticoid receptors, which results in persistent dysfunction of hippocampal networks in adulthood.

\section{References}

Abe H, Hidaka N, Kawagoe C, Odagiri K, Watanabe Y, Ikeda T, Ishizuka Y, Hashiguchi H, Takeda R, Nishimori T, Ishida Y (2007) Prenatal psychological stress causes higher emotionality, depression-like behavior, and elevated activity in the hypothalamo-pituitary-adrenal axis. Neurosci Res 59:145-151.

Andrade JP, Lukoyanov NV, Paula-Barbosa MM (2002) Chronic food restriction is associated with subtle dendritic alterations in granule cells of the rat hippocampal formation. Hippocampus 12:149-164.

Beaumont K, Fanestil DD (1983) Characterization of rat brain aldosterone receptors reveals high affinity for corticosterone. Endocrinology 113: 2043-2051.

Champagne FA, Meaney MJ (2006) Stress during gestation alters postpartum maternal care and the development of the offspring in a rodent model. Biol Psychiatry 59:1227-1235.

de Kloet ER, Joëls M, Holsboer F (2005) Stress and the brain: from adaptation to disease. Nat Rev Neurosci 6:463-475.

Han F, Ozawa H, Matsuda K, Nishi M, Kawata M (2005) Colocalization of mineralocorticoid receptor and glucocorticoid receptor in the hippocampus and hypothalamus. Neurosci Res 51:371-381.

Hosseini-Sharifabad M, Hadinedoushan H (2007) Prenatal stress induces learning deficits and is associated with a decrease in granules and CA3 cell dendritic tree size in rat hippocampus. Anat Sci Int 82:211-217.

Hsu D (2007) The dentate gyrus as a filter or gate: a look back and a look ahead. Prog Brain Res 163:601-613.

Hügin-Flores ME, Steimer T, Aubert ML, Schulz P (2004) Mineralo- and glucocorticoid receptor mRNAs are differently regulated by corticosterone in the rat hippocampus and anterior pituitary. Neuroendocrinology 79:174-184

Joëls M (2007) Role of corticosteroid hormones in the dentate gyrus. Prog Brain Res 163:355-370.

Joëls M, Karst H, DeRijk R, de Kloet ER (2008) The coming out of the brain mineralocorticoid receptor. Trends Neurosci 31:1-7.

Kerr JE, Beck SG, Handa RJ (1996) Androgens modulate glucocorticoid receptor mRNA, but not mineralocorticoid receptor mRNA levels, in the rat hippocampus. J Neuroendocrinol 8:439-447.

Kesner RP (2007) A behavioral analysis of dentate gyrus function. Prog Brain Res 163:567-576.

Koyama R, Muramatsu R, Sasaki T, Kimura R, Ueyama C, Tamura M, Tamura N, Ichikawa J, Takahashi N, Usami A, Yamada MK, Matsuki N, Ikegaya Y (2007) A low-cost method for brain slice cultures. J Pharmacol Sci 104:191-194.

Lan NC, Graham B, Bartter FC, Baxter JD (1982) Binding of steroids to mineralocorticoid receptors: implications for in vivo occupancy by glucocorticoids. J Clin Endocrinol Metab 54:332-342.

Lemaire V, Koehl M, Le Moal M, Abrous DN (2000) Prenatal stress produces learning deficits associated with an inhibition of neurogenesis in the hippocampus. Proc Natl Acad Sci U S A 97:11032-11037.

Martínez-Téllez RI, Hernández-Torres E, Gamboa C, Flores G (2009) Prenatal stress alters spine density and dendritic length of nucleus accumbens and hippocampus neurons in rat offspring. Synapse 63:794-804.

Meek LR, Dittel PL, Sheehan MC, Chan JY, Kjolhaug SR (2001) Effects of stress during pregnancy on maternal behavior in mice. Physiol Behav 72:473-479.

Michelsen KA, van den Hove DL, Schmitz C, Segers O, Prickaerts J, Steinbusch HW (2007) Prenatal stress and subsequent exposure to chronic mild stress influence dendritic spine density and morphology in the rat medial prefrontal cortex. BMC Neurosci 8:107.
Morley-Fletcher S, Darnaudery M, Koehl M, Casolini P, Van Reeth O, Maccari S (2003) Prenatal stress in rats predicts immobility behavior in the forced swim test. Effects of a chronic treatment with tianeptine. Brain Res 989:246-251.

Morris RG (2006) Elements of a neurobiological theory of hippocampal function: the role of synaptic plasticity, synaptic tagging and schemas. Eur J Neurosci 23:2829-2846.

Muramatsu R, Ikegaya Y, Matsuki N, Koyama R (2007) Neonatally born granule cells numerically dominate adult mice dentate gyrus. Neuroscience 148:593-598.

Nakahara S, Tamura M, Matsuki N, Koyama R (2009) Neuronal hyperactivity sustains the basal dendrites of immature dentate granule cells: timelapse confocal analysis using hippocampal slice cultures. Hippocampus 19:379-391.

Nakao K, Matsuyama K, Matsuki N, Ikegaya Y (2004) Amygdala stimulation modulates hippocampal synaptic plasticity. Proc Natl Acad Sci U S A 101:14270-14275.

Nestler EJ, Barrot M, DiLeone RJ, Eisch AJ, Gold SJ, Monteggia LM (2002) Neurobiology of depression. Neuron 34:13-25.

Patchev VK, Almeida OF (1996) Gonadal steroids exert facilitating and "buffering" effects on glucocorticoid-mediated transcriptional regulation of corticotropin-releasing hormone and corticosteroid receptor genes in rat brain. J Neurosci 16:7077-7084.

Pinkernelle J, Abraham A, Seidel K, Braun K (2009) Paternal deprivation induces dendritic and synaptic changes and hemispheric asymmetry of pyramidal neurons in the somatosensory cortex. Dev Neurobiol 69:663-673.

Porsolt RD, Anton G, Blavet N, Jalfre M (1978) Behavioural despair in rats: a new model sensitive to antidepressant treatments. Eur J Pharmacol 47:379-391.

Reul JM, de Kloet ER (1985) Two receptor systems for corticosterone in rat brain: microdistribution and differential occupation. Endocrinology 117:2505-2511.

Santarelli L, Saxe M, Gross C, Surget A, Battaglia F, Dulawa S, Weisstaub N, Lee J, Duman R, Arancio O, Belzung C, Hen R (2003) Requirement of hippocampal neurogenesis for the behavioral effects of antidepressants. Science 301:805-809.

Seckl JR (2004) Prenatal glucocorticoids and long-term programming. Eur J Endocrinol 151 [Suppl 3]:U49-U62.

Seki T, Arai Y (1991) The persistent expression of a highly polysialylated NCAM in the dentate gyrus of the adult rat. Neurosci Res 12:503-513.

Seki T, Arai Y (1993) Highly polysialylated neural cell adhesion molecule (NCAM-H) is expressed by newly generated granule cells in the dentate gyrus of the adult rat. J Neurosci 13:2351-2358.

Seki T, Namba T, Mochizuki H, Onodera M (2007) Clustering, migration, and neurite formation of neural precursor cells in the adult rat hippocampus. J Comp Neurol 502:275-290.

Sheline YI (1996) Hippocampal atrophy in major depression: a result of depression-induced neurotoxicity? Mol Psychiatry 1:298-299.

Stranahan AM, Arumugam TV, Lee K, Mattson MP (2010) Mineralocorticoid receptor activation restores medial perforant path LTP in diabetic rats. Synapse 64:528-532.

Swinny JD, O’Farrell E, Bingham BC, Piel DA, Valentino RJ, Beck SG (2010) Neonatal rearing conditions distinctly shape locus coeruleus neuronal activity, dendritic arborization, and sensitivity to corticotrophin-releasing factor. Int J Neuropsychopharmacol 13:515-525.

Tozuka Y, Wada E, Wada K (2009) Diet-induced obesity in female mice leads to peroxidized lipid accumulations and impairment of hippocampal neurogenesis during the early life of their offspring. FASEB J 23:1920-1934.

Weinstock M (2007) Gender differences in the effects of prenatal stress on brain development and behaviour. Neurochem Res 32:1730-1740.

Yang J, Young MJ (2009) The mineralocorticoid receptor and its coregulators. J Mol Endocrinol 43:53-64. 